\title{
Actitud terapéutica ante sacos foliculares de terceros molares incluídos
}

\section{Therapeutic approach to impacted third molar follicles}

\author{
R. González García', V. Escorial Hernández', A. Capote Moreno', \\ P.L. Martos Díaz', J. Sastre Pérez², F.J. Rodríguez Campo ${ }^{2}$
}

Resumen: El quiste dentígero o folicular es un quiste odontogénico del desarrollo. Está revestido por el epitelio del folículo dentario, y suele estar en relación con un diente permanente incluído. Presentamos el caso clínico de un paciente en el que se observa la aparición de un quiste dentígero a partir del saco folicular de un tercer molar incluído no exodonciado, y lo comparamos con la evolución de un cordal incluído y su saco folicular contralaterales en los que se realizó la exodoncia. El tratamiento definitivo del quiste dentígero asociado a un tercer molar incluído es quirúrgico, con la exodoncia de la pieza y enucleación del quiste. Los sacos foliculares mayores de $2 \mathrm{~mm}$ asociados a terceros molares incluídos evolucionan en numerosas ocasiones a quistes foliculares. Está indicada la exodoncia de dichos cordales para evitar la evolución a quiste dentígero.

Palabras clave: Quiste dentígero; Folículo dental; Tercer molar; Diente incluído.

Recibido: 07-07-2004

Aceptado: 20-10-2004
Abstract: The dentigerous cyst or follicular cyst is a developmental odontogenic cyst. It is covered by the epithelium of the dental follicle, and it tends to be related to an impacted permanent tooth. The case report of a patient who was seen to develop a dentigerous cyst arising from the follicle of an impacted non-extracted third molar is presented. This is then compared with the evolution of the contralateral impacted third molar and its follicle that was extracted. The definitive treatment for a dentigerous cyst associated with an impacted third molar is surgical, the extraction of the tooth and enucleation of the cyst. Follicles measuring more+ than $2 \mathrm{~mm}$ and that are associated with impacted third molars often develop into follicular cysts. The extraction of these third molars is indicated in order to avoid the development of a dentigerous cyst.

Key words: Dentigerous cyst; Follicle; Third molar; Impacted tooth.

\footnotetext{
1 Médico Residente.

2 Médico Adjunto.

Servicio de Cirugía Oral y Maxilofacial

Hospital Universitario de La Princesa, Madrid, España.
}

\section{Correspondencia:}

Raúl González García

C/ Los Yébenes no $35,8^{\circ} \mathrm{C}$

28047 Madrid, España

E-mail: raugg@mixmail.com 


\section{Introducción}

El quiste dentígero o folicular es un quiste odontogénico del desarrollo. Es el segundo en frecuencia tras el quiste radicular, y está revestido por el epitelio del folículo dentario.' Frecuentemente se presenta en relación con un diente permanente incluído, con más frecuencia el tercer molar inferior. ${ }^{2}$ Lo habitual es que sea central o coronario y asintomático.

Las indicaciones para la exodoncia de terceros molares incluídos son en muchos casos controvertidas. ${ }^{3}$ No hay un acuerdo general sobre la exodoncia del cordal asintomático. Es necesario considerar las posibles complicaciones de una exodoncia al plantear la indicación de cirugía.

La presencia de una lesión quística asociada a tercer molar inferior es indicativa de exodoncia y quistectomía. Sin embargo, cuando la formación quística no es evidente, y en su lugar aparece una imagen radiolúcida compatible con el saco folicular de la pieza incluída, la indicación de exodoncia profiláctica se hace más problemática, sobre todo si se considera la nada inususal evolución espontánea de un saco folicular a quiste dentígero.

\section{Caso clínico}

Paciente varón de 28 años que acude a nuestro Servicio presentando dolor hemimandíbular izquierdo y fiebre. No presenta antecedentes patológicos de interés. La exploración física no refleja ningún signo específico, pero sí dolor a la palpación de los tejidos pericoronarios del tercer molar inferior izquierdo. Se realiza analítica de Urgencias observando un leve aumento del número de leucocitos, sin otra alteración destacable. En la ortopantomografía (OPG) se visualizan ambos terceros molares incluídos, en posición mesioangular, con sendos sacos foliculares, el derecho de mayor tamaño (Fig. 1). Con la sospecha de posible infección de causa odontógena (pericoronaritis) se instaura tratamiento antibiótico, con resolución completa del cuadro. Se recomienda exodoncia de ambos cordales inferiores. El estudio histológico confirmó la presencia de un saco folicular asociado al cordal, formado por epitelio poliestratificado no queratinizado. Tras la extracción del tercer molar inferior izquierdo el paciente no acude para completar el tratamiento. A los 20 meses consulta de nuevo por presentar dolor a nivel del tercer molar inferior derecho. En la OPG se aprecia una imagen radiolúcida de gran tamaño en torno a la corona del cordal inferior derecho (Fig. 2). Con la sospecha diagnóstica de quiste dentígero asociado a tercer molar se realiza intervención quirúrgica con exodoncia de la pieza y quistectomía. El estudio anatomopatológico confirmó el diagnóstico de presunción, como una lesión con pared de tejido conjuntivo revestido en su interior por un epitelio estratificado de células ciliares queratinizadas y células con abundante mucina. En la revisión a los controversial. ${ }^{3}$ There is no general consensus as to the extraction of asymptomatic third molars. On considering the need for surgery, the possibility of extraction complications should be taken into account.

The presence of a cystic lesion associated with an inferior third molar is indicative of the extraction and a cystectomy. However, when there is no evidence of cystic formation, and if in its place there is a radiolucent image compatible with the follicle of the impacted tooth, the indications for prophylactic extraction become more problematic, especially taking into account the not uncommon spontaneous evolution of a follicle into a dentigerous cyst.

\section{Case report}

Male patient, 28 years old attended our Service presenting hemimandibular pain on the left side and a high temperature. He had no pathologic background of interest. The physical examination did not reveal any specific signs, but there was pain on palpating the pericoronal tissue of the left lower third molar. Emergency tests were requested as a slight increase in the number of leukocytes was observed with no other obvious alterations. In the orthopantomography (OPG) both impacted third molars were visible, in a mesioangular position together with both the follicles, the right one being larger (Fig. 1). As a possible infection of odontogenic origin (pericoronitis) was suspected, antibiotic treatment was initiated, and the various symptoms were completely resolved. Extraction of both inferior third molars was recommended. The histological study confirmed the presence of a follicle associated with the third molar, formed by a polystratified non-keratinized epithelium. Following the extraction of the lower left third molar the patient did not return to complete the treatment. Twenty months later he attended again as he was experiencing pain in the lower right third molar. In the OPG a large radiolucent image could 
tres meses se verificó el adecuado proceso de osificación activa (con formación de trabéculas óseas) de la cavidad residual generada por el quiste (Fig. 3).

\section{Discusión}

El quiste dentígero es una lesión frecuente. Dentro de los quistes odontógenos constituye el segundo en frecuencia tras el quiste radicular. Afecta mayoritariamente a pacientes entre los 10 y los 30 años, con un ligero predominio del sexo masculino. ${ }^{1}$ La imagen radiológica típica la constituye una lesión radiolúcida bien circunscrita, unilocular y normalmente simétrica alrededor de la corona de un diente incluído. Algunos, sin embargo, son multiloculares e irregulares. ${ }^{4}$ Se origina a partir del epitelio del esmalte, tras el inicio de la formación de la corona del diente. Su localización más habitual es la región del tercer molar, y son más comúnmente solitarios. ${ }^{2}$ Siguen en frecuencia decreciente: canino maxilar, tercer molar maxilar y segundo premolar mandibular.

Las indicaciones para la exodoncia de terceros molares incluídos son controvertidas. No todos precisan intervención quirúrgica. Para algunos autores, la presencia de cambios patológicos en los terceros molares incluídos asintomáticos y sin cambios radiológicos previos es infrecuente, y por tanto no se recomienda la exodoncia profiláctica si no hay clínica o alteraciones en las pruebas de imagen.3,5 Otros autores, por el contrario, afirman que existe un riesgo de cambios patológicos en el tejido pericoronario de terceros molares impactados, y que dicho riesgo aumenta con la edad. Recomiendan la exodoncia profiláctica antes de la aparición de cambios patológicos.6,7 La edad es importante en cuanto a la indicación de intervención quirúrgica. La morbilidad es menor si la exodoncia se practica en pacientes jóvenes. Probablemente, en pacientes de 30-40 años asintomáticos, sea preferible el seguimiento, y si se producen cambios patológicos proceder a la exodoncia. ${ }^{8}$

Es precisa la exodoncia de terceros molares incluídos en los que existe una evidencia de cambios patológicos irreversibles, asimismo se recomienda mantener los erupcionados sanos para posibles necesidades ortodóncicas futuras, existe poca evidencia para la extracción de cordales con el objetivo de minimizar posibles apiñamientos presentes o futuros, y no existe consenso con respecto a la exodoncia de cordales incluídos asintomáticos y sin patología asociada. ${ }^{9}$

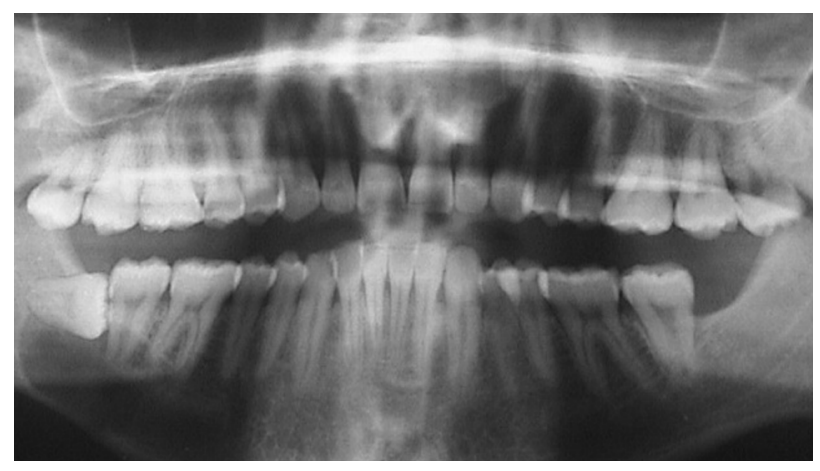

be appreciated around the crown of the lower right third molar (Fig. 2). With the suspected diagnosis of a dentigerous cyst associated with a third molar, surgical treatment was carried out, the tooth was extracted and a cystectomy performed. The anatomopathologic study confirmed the suspected diagnosis of a lesion with a wall of conjunctive tissue lined on the inside by a stratified epithelium of ciliated keratinized cells and with an abundance of mucous cells. During the follow-up at three months, an active ossification process was observed (with formation of bone trabeculae) in the residual cavity generated by the cyst (Fig. 3), which was considered adequate.

\section{Discussion}

The dentigerous cyst is a common lesion. It is the second most common odontogenic cyst following the radicular cyst. It mainly affects patients between the ages of 10 and 30, and it is slightly more predominant in the male sex. ${ }^{1}$ The radiological image is characterized by a well-circumscribed, unilocular and normally symmetric radiolucent image around the crown of an impacted tooth. Some, however, are multilocular and irregular. ${ }^{4}$ It originates from the enamel epithelium when the crown of the tooth is starting to be formed. It is usually found in the region of the third molar, and they are more commonly an isolated finding. ${ }^{2}$ They occur with a descending frequency: maxillary canine, third maxillary molar and second mandibular premolar.

The indications for the extraction of impacted third molars are controversial. Not all require surgical treatment. For some authors, the presence of pathological changes in impacted asymptomatic third molars having no previous radiological changes is infrequent and, as a result, prophylactic surgical removal is not recommended if there are no clinical or changes in the imaging tests. 3,5 Other authors, on the contrary, affirm that there is a risk of pathological change in the pericoronal tissue of impacted third molars, and that this 
Con respecto a los quistes dentígeros es conocido que pueden expandirse a través del hueso originando fracturas patológicas. El riesgo de sobreinfección aumenta también con el tamaño, se pueden presentar con dolor, inflamación y eritema, y pueden provocar resorción radicular si están en contacto con otros dientes adyacentes. ${ }^{1}$ El diagnóstico se basa en los hallazgos radiológicos e histológicos.

El tratamiento habitual del quiste dentígero asociado a un tercer molar incluído es la enucleación del mismo junto con exodoncia del diente. Los quistes de gran tamaño pueden tratarse también con marsupialización y posterior resección completa en un segundo tiempo, o bien colocación de un drenaje para reducir la presión y tamaño del quiste, y enucleación posterior. Si se consigue la resección completa, el pronóstico es excelente y la recurrencia rara. De modo excepcional, un quiste dentígero no tratado puede evolucionar a ameloblastoma, carcinoma de células escamosas o carcinoma mucoepidermoide. ${ }^{1}$

El presente caso muestra la evolución espontánea de un saco folicular de tercer molar incluído a un quiste dentígero. El diagnóstico de presunción se realizó sobre la base de una lesión radiolúcida de más de $2 \mathrm{~mm}$ en la ortopantomografía (OPG). Se obtuvo confirmación diagnóstica con el estudio histológico posterior. Una lesión radiológica similar a la anterior, de localización contralateral, sufrió diferente evolución, al ser extirpada junto con su diente incluído, de modo profiláctico, en el mismo paciente.

En nuestra experiencia clínica, y en concordancia con trabajos previos, ${ }^{10-12}$ consideramos que imágenes radiolúcidas de más de 2$3 \mathrm{~mm}$ obtenidas en la OPG, alrededor de un tercer molar incluído, traducen una alta probabilidad de evolución a quiste dentígero a partir de un saco folicular. En estos casos recomendamos exodoncia profiláctica del diente incluído junto con extirpación del saco folicular. Aquellos casos en los que la imagen radiolúcida es menor de $2 \mathrm{~mm}$ y se exodoncian de modo profiláctico no se remiten de rutina a estudio anatomopatológico, por lo que desconocemos la incidencia real de quistes dentígeros asociados a sacos menores de $2 \mathrm{~mm}$. El criterio que se utiliza para diferenciar un saco folicular de un quiste folicular está basado en mediciones empíricas, considerándose normal y propio del saco folicular un tamaño hasta 2-3 $\mathrm{mm} .{ }^{12} \mathrm{~A}$ pesar de esto, algunos autores afirman que la incidencia de quistes dentígeros asociados con terceros molares incluídos es mayor que lo estimado a partir de los estudios radiológicos aisladamente. ${ }^{11,13}$

\section{Conclusiones}

Sería deseable la realización de estudios pormenorizados con el objetivo de establecer valores de referencia en el tamaño de las imágenes radiolúcidas pericoronarias de terceros molares incluídos, y su relación con una probabilidad aumentada de presencia de (o evolución a) quiste dentígero diagnosticado histológicamente. Esto permitiría adoptar una actitud terapéutica agresiva en casos con probabilidad alta de formación de un quiste, evitando o disminuyendo los efectos deletéreos de ella derivados. risk increases with age. They recommend prophylactic surgical removal before the onset of pathological changes. ${ }^{6,7}$ Age is important with regard to the indication for surgical treatment. Morbidity is lower if the extraction is carried out in younger patients. Probably, in asymptomatic patients aged 30 to 40, periodical examination is preferable, and extraction should be carried out if there are pathological changes. ${ }^{8}$

The extraction of impacted third molars is necessary if there is evidence of irreversible pathological changes, and likewise erupted healthy teeth should be kept for possible orthodontic needs in the future. There is little evidence that third molars should be extracted in order to minimize overcrowding either at the time or in the future, and neither is there consensus as to the extraction of asymptomatic impacted third molars having no associated pathology. ${ }^{9}$

With regard to dentigerous cysts, the fact that they can expand through the bone leading to pathological fractures is well known. The risk of infection increases also with size and pain, inflammation and erythema can appear. Radicular resorption can occur if there is contact with neighboring teeth. ${ }^{1}$ Diagnosis is based on radiological and histological findings.

The usual treatment for a dentigerous cyst associated with an impacted third molar is its enucleation together with the extraction of the tooth. Large cysts can also be treated with marsupialization, and they can be completely resected at a later date, or drainage can be placed in order to reduce the pressure and size of the cyst, and it can later be enucleated. If complete resorption is achieved, the prognosis is excellent and recurrence is rare. Exceptionally, a dentigerous cyst that is not treated can evolve into an ameloblastoma, squamous cell carcinoma or mucoepidermoid carcinoma. ${ }^{1}$

The present case shows the spontaneous evolution of a follicle of an impacted third molar into a dentigerous cyst. The presumed diagnosis was made on the basis of a radiolucent lesion that measured more than $2 \mathrm{~mm}$ in the orthopantomography (OPG). The posterior histological study confirmed the diagnosis. In the same patient, a radiological lesion similar to this one, but on the contralateral side, had a different evolution on being removed with the impacted tooth as a prophylactic measure.

In our clinical experience, and in concordance with previous works, ${ }^{10-12}$ we consider that radiolucent images of more than 2-3 mm obtained in the OPG around an impacted third molar, mean that there is a high probability of it evolving from a follicle into a dentigerous cyst. In these cases we recommend the prophylactic extraction of the impacted tooth together with the follicle. In those cases in which the radiolucent image is less than $2 \mathrm{~mm}$ and prophylactic extraction takes place, routine anatomopathologic studies are not carried out, so the real rate of dentigerous cysts associated with follicles measuring less than $2 \mathrm{~mm}$ is not known. The criteria used to differentiate between a follicle and a follicular cyst is based on empirical measurements. A follicle mea- 


\section{Bibliografía}

1. Aziz SR, Pulse C, Dourmas Ma, Roser SM. Inferior alveolar nerve paresthesia associated with a mandibular cyst. J Oral Maxillofac Surg 2002;60:457-9.

2. Shah N, Thuau H, Beale I. Spontaneous regression of bilateral dentigerous cyst associated with impacted mandibular third molars. Br Dent / 2002;26;192: 756.

3. Eliasson S, Heindhal A, Noredemra A. Pathological changes related to long-term impaction of third molars. A radiographic study. Int J Oral Maxillofac Surg 1989;18:210-2.

4. Tsukamoto G, Sasaki K, Akiyama T, y cols. A radiologic analysis of dentigerous cysts and odontogenic keratocysts associated with a mandibular third molar. Oral Surg Oral Med Oral Pathol Oral Radiol Endod 2001;91:743-7.

5. Albertos Castro JM, Junquera Gutiérrez LM. Exodoncia selectiva de terceros molares. Rev Esp Cir Oral Maxilofac 2003;25:9-15.

6. Rakprasitkul S. Pathologic changes in the pericoronal tissues of inerrupted third molars. Quintessence Int 2001;32:633-8.

7. Costas López A. Exodoncia rutinaria de terceros molares. Rev Esp Cir Oral Maxilofac 2003;25:17-20.

8. Olson JW, Miller RI, Kushner GM, Vest TM. Odontogenic carcinoma ocurring in a dentigerous cyst: a case report and clinical management. J Periodontol 2000; 71:1365-70.

9. Stanley HR, Alattar M, Collet WK, Stringfellow HR Jr, Spiegel EH. Pathological sequelae of «neglected» impacted third molars. / Oral Pathol 1988;17:113-7.

10. Manganaro AM. The likelihood of finding occult histopathology in routine third molar extractions. Gen Dent 1998;46:200.

11. Adelsperger J, Campbell JH, Coates DB, Summerlin DJ, Tomich CE. Early soft tissue pathosis associated with impacted third molars without pericoronal radiolucency. Oral Surg Oral Med Oral Pathol Oral Radiol Endod 2000;89:402.

12. Vallecillo M. Quistes de los maxilares. En: Vascones A. Tratado de odontología. Madrid: Trigo Ediciones S.L, 1998; p.p. 3761.

13. Glosser JW, Campbell JH. Pathologic change in soft tissues associated with radiographically «normal» third molar impactions. Br J Oral Maxillofac Surg 2000;38: 402. suring 2-3 mm is considered typically normal. ${ }^{12}$ In spite of all this, some authors claim that the incidence of dentigerous cysts associated with impacted third molars is greater than has been assumed from radiological studies alone. ${ }^{11,13}$

It would be desirable for detailed studies to be carried out with the aim of establishing reference values regarding the size of radiolucent pericoronal images of impacted third molars, and the relationship with an increase in the probability of the cysts being, or becoming, a histologically diagnosed dentigerous cyst. This would allow an aggressive therapeutic approach to be adopted in cases with a high probability of cystic formation, and the resulting deleterious effects could be avoided or diminished. 